dr. Sabina

Jelenc

Krašovec

Filozofska

fakulteta $v$

Ljubljani

\title{
Univerza kot del učeče se družbe
}

prispevku obravnavam razmerje med univerzo in učečo se družbo. Na prvi pogled gre za nasprotujoči si ideji: za idejo približevanja univerze kot institucije, ki s tradicionalno avtonomijo in akademskim pristopom $\mathrm{k}$ znanju in védenju že stoletja ohranja pomembno vlogo v družbi, in idejo učeče se družbe kot koncepta, ki vnaša drugačne vrednote $v$ pojmovanje učenja in izobraževanja. Pri njunem vzporejanju je temeljno vprašanje pripravljenosti univerze, da se spreminja in približuje načelom učeče se družbe, ki temeljijo na strategiji vseživljenjskosti učenja in izobraževanja. Spreminjanje v tej smeri je značilno za mnoge podjetniške in druge organizacije, ki težijo k odprtosti, prilagodljivosti, stalnemu razvoju in povezovanju $\mathrm{z}$ drugimi subjekti v družbi.

Vseživljenjsko izobraževanje ni nov pojem, saj se kot strategija pojavlja že od šestdesetih let, ko so njegov pomen pri spreminjanju vloge izobraževanja $v$ družbi začeli poudarjati različni avtorji (Faure, Husen, Illich, Lengrand in drugi). Šlo je predvsem za težnje po preseganju stereotipov, kot je ta, da je izobraževanje omejeno s starostjo in šolo (ter drugimi izobraževalnimi institucijami), ki so mu kot ustreznejše alternative postavljali pojmovanje učenja in izobraževanja kot vseživljenjskega procesa, razvijanje omrežij učenja, pri čemer bo učenje prepleteno $\mathrm{z}$ drugimi življenjskimi vlogami, ki bodo pripomogle $\mathrm{k}$ večji neodvisnosti in kritičnosti učečih se, težnje po večji dostopnosti do učenja na podlagi alternativnih in bolj odprtih možnosti ter druge ukrepe, s katerimi bi povečevali strategijo enakih možnosti.
Možnosti za uveljavljanje te strategije povečuje hiter razvoj informacijske tehnologije, ki omogoča neomejeno razširjanje znanja in informacij v vse družbene segmente. Za uveljavljanje strategije vseživljenjskosti učenja in izobraževanja je ključno, da se povezujeta formalno in neformalno izobraževanje, in sicer s partnerstvom med individualno, institucionalno in nacionalno ravnjo.

\section{UVELJAVLJANIE STRATEGIJE VSEŽIVLJENSKEGA UČENJA IN IZO- BRAŽEVANIA $Z$ VIDIKA UNIVERZE IN DRUGIH INSTITUCI] V DRUŽBI}

$\mathrm{V}$ razvijajoči se družbi ima pomembno vlogo tudi univerza, ki je bila doslej bolj odmaknjena od konkretnih družbenih potreb in ki je s povečevanjem različnih alternativnih možnosti izobraževanja pred izzivom brez primere. Uveljavljanje ideje učeče se družbe bi vplivalo tudi na spreminjanje zahtev do univerze. Spreminjala naj bi se $v$ organizaciji sami in tudi v povezovanju $\mathrm{z}$ družbo. Kot temeljna raziskovalna institucija in središče znanja, védenja in razumskosti $v$ družbi naj ne bi bila toga, zaprta institucija; $z$ ohranjanjem avtonomije, ki bi zagotavljala ustrezno neodvisnost od $\mathrm{dr}$ Žavnih, ekonomskih in političnih subjektov, ustvarjanjem notranje trdnosti in integriranosti, ki bi to avtonomijo zagotavljala, naj bi postala odprta, odzivna in učeča se akademska skupnost. Le taka bo $\mathrm{v}$ prihodnje ustrezala potrebam različnih subjektov, ki v družbi potrebujejo znanje. 
Struktura, delovanje in cilji univerze $\mathbf{v}$ »učeči se družbi«

Spreminjanje univerze je potrebno in nujno, da bi še lahko ohranjala svoje pomembno mesto v družbi.

Univerza, kot del učeče se družbe, naj bi ob upoštevanju svojega poslanstva spodbujala tudi čim več navedenih predpostavk:

a) spoštovala in uresničevala naj bi načelo vseživljenjskosti učenja ter izobraževanja in povečala dostop odraslih do visokošolskega študija - to bi dosegala predvsem z vključevanjem različnih starostnih in interesnih skupin v izobraževanje ter učenje na univerzi, kar naj bi podprla $\mathrm{z}$ razširitvijo ponudbe programov za odrasle in uvajanjem sodobnejših pristopov; tako bi zadovoljevala ekonomske, socialne, kulturne in druge potrebe različnih zainteresiranih skupin;

b) presegala naj bi udejanjanje načela operativnosti in akademskosti - za to bi bila potrebna nadgradnja operativnih in akademskih kompetenc s tretjim sklopom znanja, ki pomeni svet življenjskih izkušenj; tako znanje naj ne bi bilo ne povsem praktično ne povsem akademsko, temveč naj bi pomagalo razumeti svet $\mathrm{z}$ alternativnimi praktičnimi in akademskimi viri; ustrezno bi bilo tudi za učečo se družbo, saj pripomore h kritičnosti, emancipaciji in argumentaciji, hkrati pa bi bilo tudi zanimivejše za zaposlovalce;

c) univerza naj bi se intenzivneje odpirala navzven in se na različnih ravneh povezovala z zunanjimi družbenimi subjekti (organizacijami, društvi, posamezniki idr.) vključevala naj bi študente $v$ različna učna omrežja in intenzivneje sodelovala tudi $\mathrm{z}$ organizacijami, kjer se diplomanti zaposlujejo; to bi omogočalo diskurzivnost študija in spoznavanje drugačnega razumevanja problemov ter s tem razvijanje etičnih vrednot študentov; s povezovanjem véde- nja, refleksije in akcije bi visokošolsko izobraževanje lahko postalo ključna institucija za uveljavljanje učeče se družbe;

č) tradicionalne metode poučevanja naj bi nadomeščala ali dopolnjevala $\mathrm{z}$ aktivnejšimi metodami poučevanja in učenja, ki diplomante pripravljajo na udeležbo v različnih družbenih dejavnostih - večji poudarek naj bi namenila usposabljanju študentov za samostojno mišljenje in dejavno učenje, pri čemer naj bi se tudi vloga poučevanja iz procesa prenašanja znanja vse bolj spreminjala $\mathrm{v}$ proces rasti in razvoja študentov;

d) v učni proces naj bi uvajala inovacije, ki so posledica tehnološkega, ekonomskega in socialnega razvoja - univerza naj bi spodbujala uvajanje izobraževanja na daV učeči se družbi mora univerza sodelovati z delovnimi organizacijami. ljavo, kreditnega sistema in modularizacije, uvajanje procesa »ugotavljanja in potrjevanja znanja«, središč za samostojno učenje in drugih pristopov, ki bi pripomogli $\mathrm{k}$ večji kakovosti dela na univerzi in njenemu kakovostnejšemu povezovanju z okoljem;

e) postopno naj bi spreminjala svoje delovanje in strukturo v smeri učeče se organizacije - pri tem naj bi si prizadevala za proaktivno strategijo in stalni razvoj, večjo notranjo integracijo in oblikovanje organskega omrežja zaposlenih na univerzi, enotnejše akademske kulture, podpornega, in ne nadzornega sistema.

\section{Predlogi za dejavnejše in plodnejše povezo- vanje univerze $z$ drugimi subjekti v družbi}

Univerza $v$ učeči se družbi naj bi bila institucija, ki se aktivno odziva na okolje, središče kritičnosti in razumskosti, razvijala naj bi kognitivno razumevanje in delovala kot akademska skupnost. Univerza naj bi bila pomemben steber civilne družbe in do zunanjih partnerjev naj bi uveljavljala ekvidi- 
stančne odnose (Svetlik, 1995). Tak model predvideva avtonomno univerzo, ki ni preveč odvisna ne od države ne od drugih part-

Univerza se mora odzivati na potrebe družbe.

nerjev, vendar se odziva na njihove potrebe. Uresničevanje teh načel zahteva notranje koherentno oziroma integrirano univerzo, saj razbita univerza ne more kljubovati zunanjim pritiskom. Več pozornosti naj bi torej namenjala drugačnemu načinu notranjega povezovanja in sodelovanja med akademskim osebjem.

\section{Univerza kot intelektualno in kulturno sre- dišče lokalne skupnosti}

Univerza naj bi bila kot učeča se univerza bolj vraščena v skupnost in naj bi se povezovala $\mathrm{z}$ različnimi organizacijami ter posamezniki v lokalni skupnosti. To bi lahko dosegla:

- $\mathrm{z}$ intenzivnejšim povezovanjem študijske dejavnosti, delovanjem zunanjih organizacij (društev, klubov, prostovoljskih organizacij, inštitutov, podjetij in drugih), kar bi vnašalo na univerzo drugačna stališča in poglede; tako bi pospešili razvijanje kritičnosti in razumskosti na univerzi in v lokalni skupnosti;

- z organiziranjem različnih delavnic, konferenc in poletnih šol, ki bi bile dostopne posameznikom in organizacijam iz ožje in širše skupnosti;

- z ustanavljanjem odprtih središč za samostojno učenje;

- $\mathrm{z}$ aktivno udeležbo $\mathrm{v}$ tednu vseživljenjskega učenja, s prireditvami, ki bi prikazovale značilnosti in potek učenja na univerzi, predstavljale novosti $\mathrm{z}$ različnih znanstvenih področij in omogočale kritične razprave o pomembnih vprašanjih, ki zanimajo učitelje, študente in širšo javnost; sodelovanjem univerze $\mathrm{z}$ drugimi umetniškimi središči;

- s partnerstvom z lokalno skupnostjo.

\section{Univerza kot sodobno in inovativno učno} središče

Univerza naj bi se (ne samo za kakovostno raziskovanje) zavzemala za kakovosten učni proces, ki bi vključeval uvajanje novih pristopov in uporabo novih tehnologij. Zanimala naj bi se tudi za potrebe lokalne skupnosti in se nanje odzivala. Tako naj bi:

- učni proces izvajala na podlagi upoštevanja različnih zahtev programov in različnih potreb študentov, aktivno in razgibano, s ciljem ustvarjati kritične diplomante;

- uvajala uporabo najnovejše informacijske tehnologije v študijski proces;

- spodbujala prenos tehnologije $\mathrm{z}$ univerze $\mathrm{v}$ skupnost in nasprotno;

- spodbujala razvijanje izobraževanja na daljavo v različnih visokošolskih programih;

- razvijala kakovostno gradivo za samostojno učenje, ki bi bilo na voljo študentom, ki se izobražujejo na daljavo, in tudi študentom v tradicionalnih programih;

- priznavala in uvajala postopke »ugotavljanja in potrjevanja znanja $\mathrm{v}^{\mathrm{v}}$ programe, kadar vsebine in cilji izobraževanja to dopuščajo;

- ustanavljala razvojno in svetovalno službo $\mathrm{v}$ visokošolskih institucijah;

- izenačevala položaj »rednih« in »izrednih« študentov.

\section{Univerza kot učeča se organizacija}

Univerza naj bi se iz strokovne birokracije postopno spremenila $v$ učečo se organizacijo. To bi dosegla:

- z upoštevanjem vseh članov univerze in spodbujanjem skupne odgovornosti za rezultate; 
- s postopnim zmanjševanjem zelo izražene akademske hierarhije, ki ne temelji le na strokovnosti, temveč na vplivih dejavnikov, ki zavirajo možnosti za medsebojno sodelovanje članov različnih hierarhičnih ravni;

- s proaktivnim delovanjem vseh članov organizacije, ki naj ne bi bilo le odgovor na zunanje zahteve in pritiske (reaktivno delovanje), temveč posledica odločitev posameznikov in skupin;

- s povezovanjem strokovnih skupin različnih znanstvenih disciplin v učna omrežja, ki bi omogočala prenašanje izkušenj in izmenjavo mnenj ter stališč tudi med oddelki in na ravni visokošolske institucije.

Z uveljavljanjem strategije vseživljenjskosti bodo v družbi verjetno postopno nastajale tudi druge razmere, potrebne za razvoj družbe v učečo se družbo. V njej bo lahko konstruktivno delovala tudi učeča se univerza, katere značilnosti bodo odprtost, fleksibilnost, občutljivost na različne potrebe $\mathrm{v}$ družbi, strpnost do različnosti, določena raven senzibilnosti za probleme lokalne skupnosti ter pripravljenost odzivati se nanje z znanjem, ki ga ima. Tudi če se koncept učeče se družbe $\mathrm{v}$ prihajajočem obdobju ne bi uveljavil, bi se morala univerza začeti prilagajati spremenjeni vlogi v prihodnosti.

\section{LITERATURA}

Argyris, C., Schön, D. (1978): Organizational Learning: A Theory of Action Perspective. Massachusets, California: Addison-Wesley Publishing Company.

Barnett, R. (1994): The Limits of Competence. Knowledge, Higher Education and Society. Buckingham: SRHE and Open University Press.

Bourgeois, E., Duke, C., Guyot, J.-L., Merill, B. (1999): The Adult University. Buckingham: SRHE and Open University Press.

Delors, J. (ed.) (1996): Učenje: skriti zaklad. Ljubljana; Ministrstvo za šolstvo in šport.

Dohmen, G. (1996): Lifelong Learning. Guidelines for a modern education policy. Bonn, Federal Ministry of Education, Science, Research and Technology.
Faure, E. idr. (1972): Learning to be. The world of education today and tomorrow. Paris: UNESCO.

Faure, E. idr. (1972): Learning to be. The world of education today and tomorrow. Paris: UNESCO.

Kump, S. (1994): Akademska kultura. Ljubljana: Znanstveno in publicistično središče.

Kump, S. (1999a): Perspektive univerze v 21. stoletju. V: Majerhold, K. (ed.). Univerza pleše avtonomno? Prispevki k repertoarju univerze za tretje tisočletje. Ljubljana: ŠOU in zavod Radio Študent.

Kump, S. (1999b): Spreminjanje odnosov med univerzo in državo. Raziskovalec, maj 1999, 10-17.

Robertson, D. (1999): Knowledge Societies, Intellectual Capital and Economic Growth. V: Gray, H. (ed.). Universities and the Creation of Wealth. Buckingham: SRHE and Open University Press.

Senge, M. P. (1990): The Fifth Discipline. The Art \& Practice of the Learning Organization. London: Century Business.

Kammler, E. (ed.). Lifelong Learning in its Impact on Social and Regional Development. Bremen: Donat

Scott, P. (1995): The Meaning of Mass Higher Education. Buckingham: SRHE and Open University Press.

Swieringa, J., Wierdsma, A. (1992): Becoming a Learning Organization. Wokingham, Reading: Addison-Wesley Publishing Company.

Watson, D., Taylor, R. (1998): Lifelong learning and the university: a post dearing agenda. London; Bristol: Falmer Press. 